Editorial

\title{
Labour Standards and Trade: In Search of Impact and Alternative Instruments
}

\author{
Jan Orbie ${ }^{1}$ and Gerda Van Roozendaal ${ }^{2, *}$ \\ ${ }^{1}$ Centre for EU Studies, Department of Political Science, Ghent University, 9000 Ghent, Belgium; E-Mail: jan.orbie@ugent.be \\ 2 Department of International Relations and International Organization, Faculty of Arts, University of Groningen, 9700 AS \\ Groningen, The Netherlands; E-Mail: g.c.van.roozendaal@rug.nl
}

* Corresponding author

Submitted: 29 November 2017 | Published: 14 December 2017

\begin{abstract}
Labour standards have become an almost routine feature of trade agreements. However, we have little knowledge about whether this linkage is effective; both in absolute terms but also in comparison to other instruments that promote labour standards on a global level. Such alternative instruments include public-private agreements, value chain management and procurement policies. The articles in this thematic issue will provide insights that further the debate on the effectiveness of the connection between labour rights and international trade, looking at both 'traditional' trade agreements and 'alternative' instruments.
\end{abstract}

\section{Keywords}

Bangladesh Sustainability Compact; global value chain; International Labour Organization; labour standards; public procurement; social clause; trade agreements

Issue

This editorial is part of the issue "Labour Standards in a Global Environment", edited by Gerda Van Roozendaal (University of Groningen, The Netherlands) and Jan Orbie (Ghent University, Belgium).

(C) 2017 by the authors; licensee Cogitatio (Lisbon, Portugal). This article is licensed under a Creative Commons Attribution 4.0 International License (CC BY).

\section{Two Generations of Research}

Until now, academic work on labour clauses in Free Trade Agreements (FTAs) has focused mainly either on understanding the background of the instrument (the 'why') or on the process side (the 'how').

First, the 'why'. The case for linking labour provisions to trade arrangements has been made from economic, normative, ideological and strategic frames (e.g. Burgoon, 2004; Charnovitz, 1987; van den Putte, 2015; Van Roozendaal, 2015; Waer, 1996). The combination of all these reasons has made such provisions less contested and resulted in a near-consensus that labour rights have a place in trade arrangements (International Labour Organization [ILO], 2015). As Kolben states in this issue, it is now more unusual not to include labour provisions in FTAs than to include them (Kolben, 2017). However, while the provisions may have made FTAs more acceptable in the eyes of those concerned about the effects of free trade, it does not mean that the trade- labour linkage has silenced the opposition to free trade or resulted in unequivocal support. The article by Riethof (2017) on Brazilian trade unions in this issue shows clearly that the debate on the underlying motivations for the labourtrade linkage continues to be relevant.

A second line of closely related research concentrates on the 'how'. Now that we have a growing number of FTAs with labour provisions, the question arises as to how they work and how they can be compared. While this research includes the 'why' question on the varying motivations, it extends it to analysing the procedures and institutions that have been established for the promotion of labour rights through trade agreements. Specifically, a large number of studies have comparatively 
analysed labour standards in US and EU trade agreements (Brown, 2015; Ebert \& Posthuma, 2013; Horn, Mavroidis, \& Sapir, 2009; ILO, 2015; Oehri, 2015), examining whether they have been inspired by protectionist or normative interests (the 'why'), while showing that the US holds a 'hard' (or 'sanctions-based') and the EU applies a 'soft' (or 'incentives-based') approach (the 'how'). Comparative analyses with non-EU and non-US FTAs are less common, however.

Meanwhile, a growing but still nascent strand of literature explores how public actors can engage in alternative ways to globally promote labour rights beyond FTAs. These studies look specifically at how public actors can facilitate private schemes for corporate social responsibility and more responsible supply chains. In a recent special issue, Burgoon and Fransen (2017) analyse the 'important but unresolved empirical controversy on the nature and effectiveness' of (the interaction between) public and private initiatives for the promotion of labour rights. They find that public interventions strengthen private labour policy while private interventions do not affect or substitute for public labour policy.

However, the literatures on 'traditional' and 'alternative' approaches to the international promotion of labour rights have only started to dig into questions of effectiveness. There is also much confusion on how impact should be conceptualised and operationalised (e.g. intermediate versus direct impact) and a lack of data about labour standard practices makes impact assessment a difficult task. Building on existing insights, this thematic issue aims to take the debate one step further by conceptualising different forms of impact, exploring different forms of effectiveness of labour provisions in existing FTAs, and examining alternative approaches beyond FTAs.

\section{Our Approach}

Our main interest in publishing this thematic issue is that we believe that the changes made to the FTAs should result in an improvement of labour standards, directly in terms of labour practices in a specific country or indirectly, i.e. the conditions for improving labour standards should be adapted in such a way that it would ultimately result in a direct impact. At the same time, we are interested in what kind of alternatives could be developed.

With regard to the first issue, the more direct impact, it should be noted that measuring this remains something of a challenge. The value of large $\mathrm{N}$-studies is restricted because of the lack of reliable data on changes in de facto labour standards worldwide. Therefore, we have chosen to concentrate in this thematic issue on contributions that focus on comparative and single case studies. Such studies provide a more detailed insight into the nature of the impact and the reasons for (a lack of) direct impact. The country studies in this volume on South Ko- rea (Van Roozendaal, 2017), Peru (Orbie, van den Putte, \& Martens, 2017), and also to a certain extent Brazil (Riethof, 2017), are illustrations of this approach. Also Oehri (2017) departs from a local perspective, examining civil society complaints in the Dominican Republic and Mexico. In addition to answering the question how trade agreements influence labour practices, the study by Gansemans, Martens, D'Haese and Orbie (2017) turns the question around, and looks at how the protection of labour standards influences market access.

Secondly, the improvement of labour practices through FTAs can also take place via the intermediate impact of the development or linkage of institutions, the changes in laws and regulations, the funding of development and the empowerment of civil groups (see also van den Putte, 2016). Different studies in this thematic issue address intermediate impact. The case study by Oehri (2017) on the US FTAs complaint procedure is an example of the development of institutions. In this thematic issue, this is also addressed in the study by Marx, Ebert and Hachez (2017), which points to improvements in the dispute settlement mechanism in EU and US FTAs. The study by Kolben (2017), on the other hand, links a supply chain approach to FTAs, while Gansemans et al. (2017) specifically analyse the supply chain of pineapples. Changing of laws and regulations and empowerment of groups are addressed in the contributions on Peru, South Korea and to a lesser extent on Brazil.

Thirdly, some interesting alternatives are being assessed and explored. The article by Martin-Ortega and O'Brien (2017) looks at the impact of public procurement, while Vogt (2017) focuses on the impact of the Bangladesh Sustainability Compact, a public-private initiative, and compares this to the effects of the private Bangladesh Accord for Fire and Building Safety.

\section{Conceptualising Impact}

Clauses on labour standards in FTAs should improve labour practices. As the model below (Figure 1) shows, we call such improvement the ultimate impact. ${ }^{1}$

This model and its elements (adapted from van den Putte, 2016, pp. 82-86) acknowledges that the intermediate impacts may not necessarily lead to the improvement of labour practices, or in some cases may be the effect of, or affect, legal improvements before achieving practical improvements. The intermediate impacts may take place in the field of development. Through an FTA, children might be supported to attend school instead of working or labour inspections might be funded (van den Putte, 2016, pp. 83-84). ${ }^{2}$ The empowerment of civil society (including trade unions), either unilaterally or in networks with businesses and government, takes place when an FTA leads to increased collaboration that strengthens the position of civil society. An intermediate impact may also be accomplished when institutions

\footnotetext{
$\overline{1 \text { van den Putte (2016, p. 82) }}$ calls it outcome impact, and Marx et al. (2017) refer to this in this issue as 'goal achievement effectiveness'.

2 van den Putte classifies the introduction of a labour inspection system as an institutional impact $(2016$, p. 83).
} 


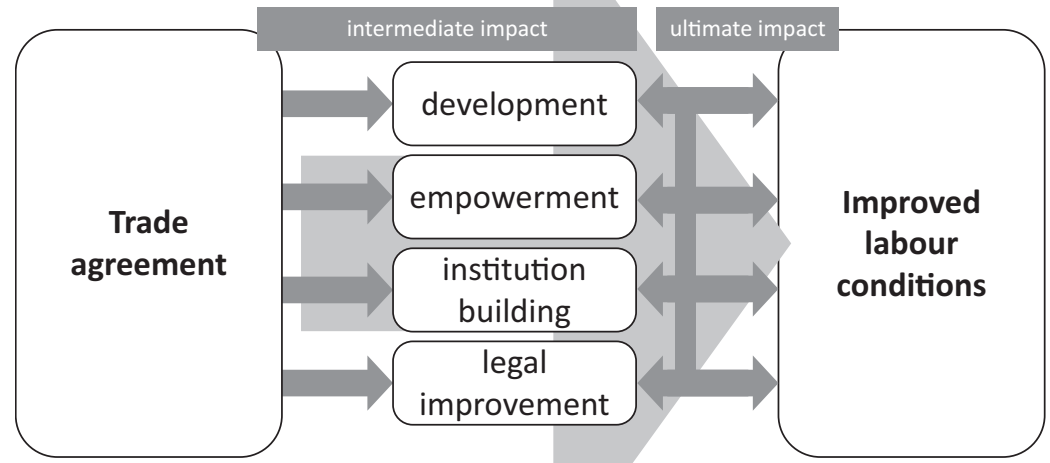

Figure 1. Conceptualising impact on labour conditions.

are built as a direct consequence of an FTA's legal requirements, e.g. for dispute settlement bodies or advisory committees. This, in turn, can affect empowerment of civil society.

Finally, legal improvements concern changes in laws and regulations, and the ratification of ILO conventions. Legal improvement may impact practices, but may also be nothing more than a paper tiger. Legal improvements may follow directly from commitments in an FTA, but may also be stimulated through civil society empowerment and institution building, for example. Finally, commitments flowing from FTAs may directly impact practices.

\section{Main Findings}

The case study by Van Roozendaal (2017) on South Korea shows no ultimate impact, even though South Korea is confronted with numerous FTAs with labour standard provisions. This suggests that until now, these provisions have not been taken seriously, either by South Korea or by any of the signatory countries. A similar lack of political will is demonstrated in the article on Peru (Orbie et al., 2017). The labour provisions in the agreement have been designed in a conservative and flexible way, and the implementation of commitments in the trade agreement also leaves much to be desired. This can be explained by the Peruvian government's neoliberal approach and the EU's reluctance to push harder for compliance with labour rights. While Peru and South Korea are very different in terms of economic development (World Bank, 2017), they are both considered to be free countries by Freedom House (2017). This does indicate that democratic countries are not necessarily interested in improving labour rights, and that this lack of interest is not necessarily explained by a lack of economic development.

If, on the basis of the above, we argue that the ultimate impact of FTAs is limited, what about the intermediate effects that might-in the medium or long run- determine the ultimate impact? The empowering effects of FTAs are related to the position of civil society and are often the effect of institution building. The articles by Orbie et al. (2017) and Van Roozendaal (2017) in this issue show that there is very limited impact. Riethof (2017) is more positive in terms of how Mercosur has created space for civil society. She also shows that civil society empowerment can be an unintended consequence of trade agreements, as opposition to the Free Trade Area of the Americas has fostered regional civil society collaboration. The clearest result comes from the study by Oehri (2017), which looks at the opportunity US FTAs provide to file complaints about non-compliance with labour rights provisions in the labour chapters of the agreements. She shows that not only powerful civil society organisations have a chance of having a compliance accepted. In this way, institutions provided for by an FTA may also increase empowerment of individuals who do not have international back-up, specific expertise or broader support (such as Father Hartley in the Dominican Republic). In addition, legal improvements were found in Brazil, where national courts made use of Mercosur's Declaration of Social and Labour Rights (see, e.g., Riethof, 2017, in this issue).

As we have found indications that FTAs have so far not lived up to the expectations of improving labour standards, should we consider them beyond repair? Two articles in this thematic issue come with innovative ideas to adjust the FTAs. Marx et al. (2017) study the dispute settlement mechanism of EU and US FTAs and arrive at the conclusion that elements of other instruments could help to fill the gaps in the current complaint and dispute settlement provisions, also by allowing more third (nonstate) parties acknowledgement. Kolben (2017) shows how labour standards could be improved by combining a supply chain approach with FTAs, creating a more tailormade instrument.

Finally, the Generalized System of Preferences may be a more effective instrument for social conditionality 
than bilateral trade agreements, provided that it is used in a legitimate way and embedded within wider social and development policies (Vogt, 2017). In this regard, Vogt (2017) points to recent developments where the EU's threat to withdraw Everything but Arms preferences for Bangladesh might induce reforms of the Bangladesh Labour Act. It remains to be seen to what extent the EU is able and willing to link unilateral trade preferences with Bangladesh's compliance with the Compact.

Despite these limited results in terms of effectiveness, several authors recognise that it may be too early to tell. Indeed, most of the labour provisions in trade agreements have only recently been established and cannot be expected to deliver immediate results. Moreover, several contributors note some optimism in terms of rising awareness of consumers and business, such as the growing international policy and national practice linking public procurement and global labour rights shows (see Martin-Ortega \& O'Brien, 2017). In this regard, a more promising avenue may be to step away from the sole focus on FTAs and pursue alternative avenues for the promotion of labour rights (see in this issue Kolben, 2017; Martin-Ortega \& O'Brien, 2017; Vogt, 2017).

Developments such as those studied in this thematic issue need our attention in the future. They should be aimed at refining the impact measurement of FTAs and at understanding why impact is limited and how it should be improved. At the same time, innovative ideas that offer additional instruments are needed.

\section{Conflict of Interests}

The authors declare no conflict of interests.

\section{References}

Brown, R. C. (2015). Asian and US perspectives on labor rights under international trade agreements compared. In A. Marx, J. Wouters, G. Rayp, \& L. Beke (Eds.), Global governance of labour rights: Assessing the effectiveness of transnational public and private policy initiatives (pp. 83-117). Cheltenham: Edward Elgar.

Burgoon, B. (2004). The rise and stall of labor linkage in globalization politics. International Politics, 41(2), 196-220.

Burgoon, B., \& Fransen, L. (2017). Might corporate social responsibility hollow out support for public assistance in Europe? British Journal of Industrial Relations. doi:10.1111/bjir.12227

Charnovitz, S. (1987). The influence of international labour standards on the world trading regime: A historical overview. International Labour Review, 126(5), 565-584.

Ebert, F. C., \& Posthuma, A. (2011). Labour provisions in trade arrangements: Current trends and perspectives. Geneva: International Institute for Labour Studies.

Freedom House. (2017). Freedom in the world. Populists and autocrats: The dual threat to global democracy. Freedom House. Retrieved from https:// freedomhouse.org/report/freedom-world/freedomworld-2017

Gansemans, A., Martens, D., D’Haese, M., \& Orbie, J. (2017). Do labour rights matter for export? A qualitative comparative analysis of pineapple trade to the EU. Politics and Governance, 5(4), 90-105.

Horn, H., Mavroidis, P. C., \& Sapir, A. (2009). Beyond the WTO? An anatomy of EU and US preferential trade agreements (Bruegel Blueprint Series: Vol. VII). Brussels: Bruegel.

International Labour Organization. (2015). Social dimensions of Free Trade Agreements: Revised edition. Retrieved from http://www.ilo.org/wcmsp5/groups/ public/---dgreports/---inst/documents/publication/ wcms_228965.pdf

Kolben, K. (2017). A supply chain approach to trade and labor provisions. Politics and Governance, 5(4), 60-68.

Martin-Ortega, O., \& Methven O'Brien, C. (2017). Advancing respect for labour rights globally through public procurement. Politics and Governance, 5(4), 69-79.

Marx. A., Ebert, F., \& Hachez, N. (2017). Dispute settlement for labour provisions in EU free trade agreements: Rethinking current approaches. Politics and Governance, 5(4), 49-59.

Oehri, M. (2015). Comparing US and EU labour governance 'near and far'-Hierarchy vs network? Journal of European Public Policy, 22(5), 731-749.

Oehri, M. (2017). Civil society activism under US Free Trade Agreements: The effects of actorness on decent work. Politics and Governance, 5(4), 40-48.

Orbie, J., Van den Putte, L., \& Martens, D. (2017). The impact of labour rights commitments in EU trade agreements: The case of Peru. Politics and Governance, 5(4), 6-18.

Riethof, M. (2017). The international labour standards debate in the Brazilian labour movement: Engagement with Mercosur and opposition to the Free Trade Area of the Americas. Politics and Governance, 5(4), 30-39.

van den Putte, L. (2015). Divided we stand: The European Parliament's position on social trade in the postLisbon era. In A. Marx, J. Wouters, G. Rayp, \& L. Beke (Eds.), Global governance of labour rights: Assessing the effectiveness of transnational public and private policy initiatives (pp. 63-82). Cheltenham: Edward Elgar.

van den Putte, L. (2016). The European Union's trade and labour linkage. Beyond the 'soft' approach? (Doctoral dissertation). Ghent University, Ghent, Belgium.

Van Roozendaal, G. (2015). The diffusion of labour standards: The case of the US and Guatemala. Politics and Governance, 3(2), 18-33.

Van Roozendaal, G. (2017). Where symbolism prospers: An analysis of the impact on enabling rights of labour standards provisions in trade agreements with South 
Korea. Politics and Governance, 5(4), 19-29.

Vogt, J. S. (2017). The Bangladesh Sustainability Compact: An effective tool for promoting workers' rights? Politics and Governance, 5(4), 80-92.

Waer, P. (1996). Social clauses in international trade.
The debate in the European Union. Journal of World Trade, 30(4), 25-42.

World Bank. (2017). Countries and economies. World Bank. Retrieved from https://data.worldbank.org/ country

\section{About the Authors}

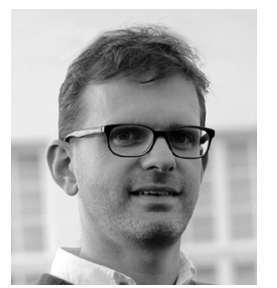

Jan Orbie is the director of the Centre for EU Studies (CEUS) and a professor at the Department of Political Science at Ghent University. His primary research focus is on the EU's foreign policy and specifically the 'soft' (trade, development, social, democracy promotion) dimensions of EU external relations. In particular, he follows closely the interaction between the trade, development and foreign policies from an EU perspective. He teaches on similar subjects within Ghent University's Master EU Studies programme.

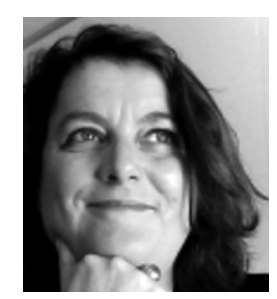

Gerda Van Roozendaal is Associate Professor at the Department of International Relations and International Organization at the University of Groningen. In 2001, she received her PhD from the University of Amsterdam. Van Roozendaal's current research interest is in how (legitimate) institutions develop and in the effectiveness of the linkage between trade agreements and labour standards. 